\title{
Optimal Allocation of English Teacher Resources in Urban and Rural Areas in Xi'an
}

\author{
Xiaoxia Lu \\ School of Foreign Studies, Xi'an University of Arts and Science, Xi'an, China \\ 1260728600@qq.com
}

Keywords: Allocation; English teacher; Resources; Urban and rural areas

\begin{abstract}
English educational equity has long been the focus issue which has been widespread concerned in China. And the education injustice is mainly caused by the irrational allocation of English teacher resources. Based on a survey and interview, the author learns and analyzes the current allocation of English teacher resources in urban and rural areas especially the differences and factors leading to the gaps in allocation of English teacher resources in rural and urban schools in Xi'an. Then suggestions are presented according to the above analysis. It hopes that English teachers in rural schools can have better salary and better training so that students in rural schools can enjoy equal English education as those in city schools do
\end{abstract}

\section{Introduction}

The National Center for Education Development Research in 2009 released veins of Chinese education policies of the annual analysis report pointed out that the allocation of teacher resources determines the quality of education and vitality of schools. [1] The fairness of educational resources' allocation, especially the resources of English teachers in urban and rural areas have been aroused much concern in China. English as a required course in all schools is paid much attention by all people in China. The allocation of the resources of English teacher in urban and rural areas most probably affects the students score in the entrance examination for universities. This issue is not only a concern for the education sector, but also for the whole community. With the shortage of English teachers in the current situation, exploring how to make limited resources of English teacher's reasonable and effective configuration can promote the fair development of English education and improve the efficiency of English education in both urban and rural areas. The study has very important practical significance.

\section{The Current Allocation of English Teacher Resources in Urban and Rural Areas in Xi'an}

With questionnaire and interview, the author has done some researches on allocation of English resources in urban and rural areas in Xi'an. The results show that the allocation of English teacher resources in rural areas greatly differs from that in urban areas in Xi'an. The main differences are as the followings.

Gap in Ratio of English Teachers to Students. According to the survey, the ratio of English teachers to students in urban schools is 11026:1 which is far greater than 67.41:1 of rural schools. The figures may have a good explanation of the present tendency that many students in rural areas rush to cities in order to enjoy the better conditions, better teaching facilities, and better faculties there. A factor that cannot be neglected is the rapid development of urbanization. Many students in rural-urban areas are now transformed to citizens of cities. Besides, many migrant workers bring with them their children to cities to share with the educational recourse of cities. Therefore, the number of students in city schools is bigger than that of the country. Moreover, $94.12 \%$ English teachers in city schools are English majors while 59.09\% English teachers in rural areas are non-English majors. This shows that rural schools are in urgent need of English majored teachers. Without professional English teachers, teachers of other subjects who may have good command of English have to take English teaching as 
their additional post. This is much serious in remote areas in the country. Therefore this makes the schools in urban areas have more advantages than those in rural areas because teachers majoring in English get better English training and have better command of the language than those non-English majors. Of course the students in city schools are the biggest beneficiaries while students may not have such luck due to the possibility of their teachers' inexpertness.

Gap of Age between English Teachers in Urban and Rural Areas. Age distribution in urban schools and rural schools also has great difference. The percentages of English teachers in urban schools between the ages of $20-35$ and the ages of 45-55 differ greatly, with $42.65 \%$ to $22.72 \%$ and $16.18 \%$ to $36.36 \%$ respectively in urban and rural schools. There is no much difference between the ages of 35-45 in urban and rural areas. This also shows that city schools attract more young teachers while those country schools cannot attract young graduates to their faculties and there will be more and more aged teachers in rural schools. Teachers between ages of 20-35, compared with those of 45-55, are easy to accept new ideas of teaching. Moreover, young teachers tend to have the same ideas with the students and they can communicate with the students easily. They bring more vigorous ideas to their teaching although they may not have enough teaching experience. Thus students in rural schools have to face with the ageing teachers who may not have the idea of introducing new ways and new concepts in their teaching, which actually leads to outdate problems in education ideas and views, and teaching means.

Gap of Academic Certificates. The differences emerge in academic certificates. The survey shows that teachers in urban areas have higher diplomas than those in rural schools. First, all the English teachers, no matter they are in rural schools or in urban schools, are college graduates which meet the requirements of being a teacher. Second, most English teachers in both rural and urban schools have bachelor's degree. Third, for the higher requirement of getting high degree, the difference between rural and urban English teachers is great. 13.24\% of English teachers in urban school have master's degree while only $6.7 \%$ of those in rural schools do. English teachers with higher diploma means they get further professional knowledge in their field and they may be able to apply what they have learned to their teaching. So students in urban schools may enjoy better teacher resources than those in the country.

Gap in Chances of Training in English Speaking Countries. When it comes to chances of training in speaking countries, English teachers in urban schools and rural schools are different. 50 English teachers in urban schools can get the chance of such training, but no English teachers in rural areas have the training. This implies that urban schools provide English teachers more chances to develop their majors and learn new ideas and method to improve their teaching whereas schools in rural areas may not have financial support for teachers to go abroad, which directly affects their teaching and of course the students' English learning to some degree. Moreover, schools in urban areas have foreign teachers who can directly provide an English language environment for the students. On the country, schools in rural areas have no English teachers from English speaking countries. So students in urban schools enjoy better teachers than those in rural schools. That's why many students in rural areas try every means to go to city schools.

Gap in Municipal Backbone Teachers. Backbone teachers play a role of model for other teachers in school. The ratio of municipal backbone English teachers in urban schools is $36.76 \%$ which is more than half of the ratio (15.91) in rural schools. Having strong sensitivity to their major and ability to do teaching research, backbone teachers are easy to accept new concept and new way of teaching to which they may try to apply in their teaching. More backbone teachers in a school means more excellent teachers in the school, which leads to good result of teaching and which may attract more students going to the school. As a result, students in urban schools are better in English than those in rural schools. 


\section{Factors Leading to the Differences}

The Origin of the Educational System. The differences between rural and urban areas deeply root in the educational policy. For a long time China takes a city-orientated educational policy which greatly improves the education of the city while education development in counties and towns cannot get effective development and cannot get much concern from the government.[2] Because of the country's urban and rural educational policy, compared with the city, the county town (rural) education has become typically "weak". Less money is invested in the development of the rural schools especially those in remote and mountainous areas. As a result, schools in rural areas cannot attract new teachers working there and the others working for a period of time may be inclined to leave for urban schools.

The Gap of the Income between People in Urban and Rural Areas. The gap of the income between people in urban and rural areas also causes the unbalanced development of English teacher resources. First of all, the difference of economic development between cities, counties and towns directly leads to the starting point of the treatment of English teachers from primary schools to senior high schools. The obvious differences make English teachers more inclined to choose better economic conditions in the area of occupation choice. Secondly, the comprehensive economic conditions of a school include the material benefits such as salary, bonus, and welfare and so on. Therefore, the flow of teachers is influenced by the development of the school and the competitiveness. More good English teachers in rural schools tend to go to teach in urban schools. Especially more and more young teachers and English major graduates choose to go to urban schools.

Differences in the Basic Conditions of Local Social Development. The basic conditions of social development include transportation facilities, scientific and technological level, information exchange, social security, medical and health, welfare facilities and other services in the social circulation and the people's living facilities and services. City has advantages in these aspects, which are the important reasons for the flow of teachers. Information gathering, academic exchange, ideas and concepts in the urban areas are superior to the counties and towns. Therefore, better teacher resources are gathered in the urban areas. Besides, urban areas can obtain more human, financial and other resources than rural areas regardless of the proportion or the total of national investment, especially in education. And such growing investment gap results in the imbalance of supply and demand of education resources, which directly lead to the backwardness of rural education conditions, teachers' low benefits and enthusiasm and decline of teaching quality. As a result English teachers in rural schools may want to leave for city schools as they have to support their families

\section{Suggestions}

National System and Policy Guarantee. To keep the balance of urban and rural allocation of teacher resources, there must be a substantial change and reform in national and policy system. A unified urban and rural public educational policy should be established so that both teachers in rural and urban areas could be treated equally and the living and development of rural teachers could be guaranteed. The urban-orient education policy should be eliminated so as to allocate fairly public education resources and teacher resources between rural and urban schools.

Salary Increase. Compared with teachers in urban schools, teachers in rural areas work harder but their salary is much lower than those in city. [3] They even don't have other welfare as the teachers in city schools do. This certainly affects their life and their social status in other people's mind. Therefore when English teachers in rural areas have high pressure to fight for a better life, they are apt to choose to leave the place for a better one. Besides, improving the level of material life of rural teachers helps to stabilize them and attract more and more excellent English teachers to rural schools. This is an important strategy to build a good team of English teachers in rural areas. Therefore, the local government should try to improve the salary and to protect the material life of rural teachers. Only when English teachers in country schools don't need to worry about their living, can they focus their attention on their teaching and try to improve themselves in their major. 
The Establishment of Motivation Mechanism. Reasonable and good incentive mechanism will help to fully tap the potential of English teachers and their motivation to work in the country. Teachers' wisdom, creativity and enthusiasm of the work can be inspired and transferred to the maximum and their efficiency of the work can be improved. So based on the state relevant policies, both the local teaching educational department and schools should launch incentive policy to reward those who perform well in their teaching in rural schools, enhancing the guiding role of incentives and mobilizing English teachers to teach. Meanwhile, the motivation mechanism should be strengthened in the rural areas to stabilize English teachers in the rural schools and attract young graduates of English major even teachers working in urban schools to work there. Through the "blood transfusion" of urban teachers to rural schools, the structure of rural teachers can be improved in a short term and the optimization of rural teachers' team can be promoted [4]

Strengthening the Professional Training of English Teachers in Rural Schools. English teachers' professional training is the basic thing to improve the quality and ability of teachers in their teaching, and it plays an important role in promoting the balance of teacher resources between rural and urban schools [5] Vygotsky (1978), who developed social constructivist theory, suggests that it is fundamental to emphasize the key role that teachers play in education equality and respect the importance of teachers work. [6] When good working and living conditions are provided and guaranteed for rural teachers, training opportunities and monetary incentives can make them stay in positions and concentrate on teaching. [7] So the education level of rural teachers should be improved continuously, and the continuing education and training of English teachers in rural areas should be strengthened. In addition the government and schools should create opportunities and conditions for rural English teachers to take part in a high level of training and overseas training, enlarging their eyesight. Thus, English teachers in the country will acquire new teaching ideas and teaching methods and improve their teaching and scientific research ability. Through education, training and continuing education and other ways, a number of outstanding rural teachers can be trained. The professional ability and professional quality of rural teachers can be developed, which achieves the "endogenous" development of rural teachers resources. [8] There are still some other ways such as increasing the communication and exchange opportunities between urban and rural English teachers. Only when the relevant measures can be effectively implemented, can the gap in English teacher resources between rural and urban areas be reasonably narrowed and the construction of the teaching staff and the quality of education can be achieved. [9]

\section{Conclusion}

Although English teacher resources configuration between rural and urban areas in recent years in $\mathrm{Xi}$ 'an had significantly improved than in the past, there are still the problems such as rural English teachers' low salary, the imbalance professional training opportunities, and no good working conditions in the rural schools and so on. To solve these problems and promote the balanced development of English education authentically, it's necessary to correct the deviation of the city-oriented policy, increase the intensity of investment in rural schools including the English teachers' professional training, incentive mechanism to attract better and more graduates to work there. Besides, the coordinated development of education between urban and rural areas should be promoted. Eventually, with good English teacher resources and good facilities in rural schools, students in rural areas will enjoy the fair English education, and the efficiency of English education in both urban and rural areas can be achieved.

\section{Acknowledgement}

Found program: the thesis is a phased achievement of the research on the balanced and quality development of English educational resources in urban and rural middle and primary schools in Xi'an Social Sciences Fund Project for Arts and Sciences (Program No.: 14WL19) 


\section{References}

[1] The Research Center National Education Development: The Annual Analysis Report of Chinese Educational Policies: 2009 Green Paper on Education in China, Beijing: Educational Science Publishing House, China (2009). (In Chinese)

[2] Zhenguo Yuan: Narrowing the Gap between Education and Promoting the Harmonious Development of Education, Education Research Journal, (2005) No.7, pp.3-11(In Chinese)

[3] Luo Li: On the Causes and Countermeasures to the Imbalance of Teacher Resources in Dazhou, Sichuan University of Arts and Science Journal, Vol. 25 (2015) No.2, pp.121-124(In Chinese)

[4] Famei Xu: Balanced Education and Communication between Urban and Rural Areas, The Modern Education Journal, (2008) No.12 pp.11-17. (In Chinese)

[5] Hong Kuang \& Xia Peng: Researches on Analysis of Causes of Imbalanced Allocation of Educational Resources and Strategies, Education Exploration, (2011) No.3, pp. 24-25. (In Chinese)

[6] Vygotsky, L.S.: Interaction between Learning and Development in L. S. Vygotsky (eds). Mind in Society: the Development of Higher Psychological Process, London: Harvard University Press, UK (1978) pp. 79-91

[7] Wu, H.: Thinking, Problems and Measures to China Education Equality Policies, Northwest University Journal, (2007) No. 2, pp. 151-155. (In Chinese)

[8] Fei Ye: From Exogenous Mode of Balance to Endogenous Mode of Balance-Discussion on Approaches to Promote Balanced Development of Teaching Faculty between Urban and Rural Areas, Journal of Theory and Practice Education, Vol. 33 (2013) No.4, pp.29-32. (In Chinese)

[9] Yanxia Sun: Researches on Allocation of Educational Resources in Primary and Secondary Schools in China (MS, Fujian Normal University, China, 2008). p.51 (In Chinese) 